\title{
Paku Epifit pada Gymnospermae di Kebun Raya Cibodas
}

\section{Epiphytic Ferns on Gymnosperms at Cibodas Botanical Garden}

\author{
RIZKIA ADHATIRANA ${ }^{1}$, NINA RATNA DJUITA ${ }^{1 *}$, SULISTIJORINI ${ }^{1}$, TAUFIKURRAHMAN NASUTION ${ }^{2}$ \\ ${ }^{I}$ Departemen Biologi, FMIPA, Institut Pertanian Bogor, Kampus IPB Darmaga, Bogor 16680 \\ ${ }^{2}$ Balai Konservasi Tumbuhan Kebun Raya Cibodas LIPI, Jl. Sindang Kaya Pacet, Cianjur-Cibodas, Cianjur 43253
}

Diterima 2 Agustus 2021/Disetujui 6 Desember 2021

\begin{abstract}
Epiphytic ferns can be found in host trees from the Angiosperm and Gymnosperm groups. Epiphytic ferns in Angiosperm plants host have been widely studied, but there is little known for Gymnosperm plants host. The aim of this study was to identify the species of epiphytic ferns in the Gymnosperm plants host at Cibodas Botanical Garden and to analyze the diversity of epiphytic ferns based on microclimate conditions and the surface texture of Gymnosperms plants host. Epiphytic ferns diversity data was obtained using purposive random sampling method. Factors that influence the occupancy of ferns are analyzed using Principal Component Analysis. Epiphytic ferns in Gymnosperm host at Cibodas Botanical Garden were identified as 18 species including 7 family. The most dominant species of epiphytic fern is Davallia denticulata (59.45\%). Diversity of epiphytic fern on Gymnosperm at Cibodas Botanical Garden is moderate $\left(\mathrm{H}^{\prime}=\mathbf{1 . 8 1}\right)$.
\end{abstract}

Key words: Epiphytic ferns, tree bark texture, dominant species

\section{PENDAHULUAN}

Tumbuhan paku merupakan tumbuhan berpembuluh yang bereproduksi menggunakan spora. Spora tumbuhan paku mudah diterbangkan oleh angin, sehingga menyebabkan penyebaran tumbuhan paku sangat luas (Aththorick et al. 2005). Paku-pakuan dapat ditemukan di berbagai habitat seperti permukaan tanah, perairan, atau menumpang pada tumbuhan lain (epifit). Salah satu tempat yang cocok untuk paku epifit adalah hutan (Lestari et al. 2019). Paku epifit berperan dalam menyumbang keanekaragaman hayati dan menjaga kelembapan lingkungan (Ulum dan Setyati 2015).

Paku epifit dapat ditemukan pada pohon inang baik dari kelompok Angiospermae maupun Gymnospermae. Keberadaan paku epifit pada pohon inang Angiospermae sudah banyak dikaji, namun untuk inang pohon Gymnospermae belum banyak diketahui. Keanekaragaman jenis paku epifit pada inangnya dapat mengalami perbedaan. Keberadaan suatu jenis paku epifit ada yang dijumpai pada jenis pohon tertentu atau pada bagian pohon tertentu saja. Sebaliknya jenis tumbuhan paku epifit lainnya dapat dijumpai pada setiap jenis pohon dan pada setiap bagian pohon. Contoh tumbuhan paku yang dapat dijumpai pada seluruh bagian pohon inang

*Penulis korespondensi:

E-mail: ninadj@apps.ipb.ac.id adalah Lycopodium sp., sedangkan Nephrolepis acutifolia melimpah pada bagian tajuk pohon inang (Sujalu 2007). Keanekaragaman jenis paku epifit dapat berbeda karena ketergantungan suatu jenis paku terhadap kondisi iklim mikro tertentu (Sujalu 2007). Keberadaan paku epifit bergantung pada kelembapan, $\mathrm{pH}$ pada batang pohon (Tewari et al. 2009), dan kulit pohon (Wyse dan Burns 2014).

Salah satu tempat yang menjadi habitat bagi paku epifit adalah Kebun Raya Cibodas, karena di tempat tersebut banyak dijumpai tumbuhan inang Gymnospermae yang sudah dikoleksi sejak lama dan umurnya sudah puluhan tahun sehingga menjadi tempat yang ideal untuk pertumbuhan paku epifit. Pohon-pohon yang sudah tua umumnya banyak yang memiliki kulit batang kasar yang memudahkan paku-pakuan untuk menempel dan hidup di situ. Kebun Raya Cibodas merupakan balai konservasi tumbuhan yang terletak di kaki Gunung Gede dan Gunung Pangrango. Tempat ini memiliki luas 84.99 hektare dan berada pada ketinggian 1,300-1,425 $\mathrm{m}$ dpl. Kebun Raya Cibodas mempunyai koleksi tanaman khas dataran tinggi beriklim basah daerah tropis dan subtropis. Kebun Raya Cibodas memiliki suhu rata-rata $20.06^{\circ} \mathrm{C}$, kelembapan relatif $80.82 \%$ dan rata-rata curah hujan $2,950 \mathrm{~mm}$ per tahun (KRC-LIPI 2019).

Paku-pakuan dapat tumbuh pada lingkungan yang berbeda-beda bergantung pada lokasi dan faktor iklim. Di Gunung Jerai, Malaysia dengan 
ketinggian 0-500 $\mathrm{m}$ dpl, paku-pakuan dapat tumbuh pada suhu sekitar $25-26^{\circ} \mathrm{C}$, kelembapan relatif 60 80\%, dan intensitas cahaya sekitar 400-800 Lux (Othman et al. 2015). Hutasuhut dan Febriani (2019) meneliti keberadaan tumbuhan paku di dataran tinggi pada ketinggian sekitar 1,400 $\mathrm{m}$ dpl di Taman Wisata Alam Sicike-Cike, Sumatera Utara. Di daerah ini, paku-pakuan dapat tumbuh pada suhu 20.27-22.60 ${ }^{\circ} \mathrm{C}$, kelembapan relatif 70.53-87.13\%, dan intensitas cahaya 7052.33 Lux-33926.67 Lux.

Kebun Raya Cibodas dipilih sebagai lokasi penelitian agar keanekaragaman tumbuhan paku epifit dapat diketahui berdasarkan kondisi iklim di dataran tinggi dan tekstur permukaan pohon inang Gymnospermae. Penelitian ini bertujuan mengidentifikasi jenis-jenis paku epifit pada pohon inang Gymnospermae yang terdapat di Kebun Raya Cibodas serta menganalisis keanekaragaman jenis paku epifit yang ditemukan berdasarkan kondisi iklim dan tekstur permukaan pohon inang Gymnospermae.

\section{BAHAN DAN METODE}

Eksplorasi Jenis Paku Epifit. Eksplorasi jenis paku epifit di Kebun Raya Cibodas (Gambar 1) dilakukan dengan metode purposive random sampling (Palinkas et al. 2015). Plot berukuran 10 x $10 \mathrm{~m}$ dibuat sebanyak 7 plot dengan 2 subplot berukuran $60 \times 50 \mathrm{~cm}$ pada bagian Timur dan Barat pohon inang kemudian dilakukan pengamatan terhadap jenis pohon inang, tekstur permukaan pohon inang, dan jenis paku epifit. Pengamatan jenis paku epifit, tekstur permukaan pohon inang, dan pengukuran iklim mikro dilakukan pada ketinggian pohon inang 0-1 meter dan 1-2 meter. Pengamatan terhadap kondisi lingkungan dilakukan dengan mengukur intensitas cahaya (Lux), suhu $\left({ }^{\circ} \mathrm{C}\right)$, kelembapan udara $(\% \mathrm{Rh})$, dan kecepatan angin $(\mathrm{m} / \mathrm{s})$ pada bulan Januari

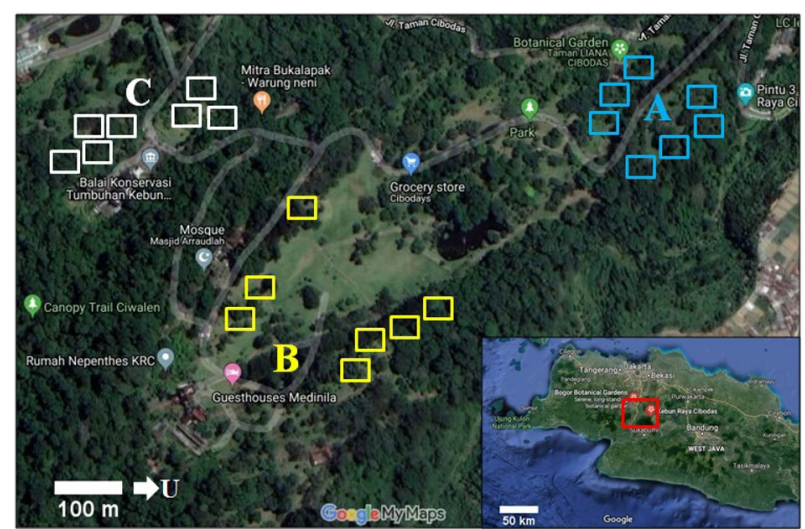

Gambar 1. Peta lokasi dan penempatan plot pengamatan di Kebun Raya Cibodas (A) vak V.C, (B) vak III.A, dan (C) vak XIII.A. Sumber: GoogleMyMaps sampai April 2019 dan data sekunder dari Badan Meteorologi Klimatologi dan Geofosika (BMKG) dari bulan Januari 2017 sampai April 2019 dari Stasiun Meteorologi Citeko, Bogor. Tekstur permukaan pohon inang yang diamati adalah ketebalan dan kekasaran kulit pohon. Ketebalan kulit pohon diukur dengan menggunakan jangka sorong. Kekasaran kulit pohon akan digolongkan menjadi beberapa golongan dan diberi skor, yaitu sangat halus (--) diberi skor 1, halus (-) diberi skor 2, agak kasar $(+)$ diberi skor 3 , kasar $(++)$ diberi skor 4, hingga sangat kasar $(+++)$ diberi skor 5 (Nainggolan 2014). Sampel paku epifit dan pohon inang diambil untuk dibuat herbarium.

Prosedur Analisis Data. Analisis data dilakukan dengan mengelompokkan data paku epifit yang ditemukan dengan data iklim yang diperoleh dari BMKG Stasiun Meteorologi Citeko, Bogor, pada bulan Januari 2017 sampai April 2019 (https://dataonline. bmkg.go.id/data_iklim), dan tekstur permukaan pohon inang Gymnospermae. Keanekaragaman jenis paku epifit dihitung menggunakan indeks keanekaragaman Shannon-Wiener (H') (Spellerberg dan Fedor 2003) Nilai H' dari indeks keanekaragaman Shannon-Wiener yang memiliki indikator kurang dari satu $\left(\mathrm{H}^{\prime}<1\right)$ menandakan tingkat keanekaragaman rendah, nilai $H^{\prime}$ di antara satu sampai $3\left(1 \leq H^{\prime} \leq 3\right)$ menandakan tingkat keanekaragaman sedang, dan nilai $\mathrm{H}^{\prime}$ lebih dari $3\left(H^{\prime}>3\right)$ menandakan tingkat keanekaragaman tinggi (Odum 1993). Keanekaragaman jenis paku epifit dihitung menggunakan indeks keanekaragaman Shannon-Wiener (H') dengan rumus:

$$
\mathrm{H}^{\prime}=\sum-P i \ln P i \text {, dengan } P i=\frac{n i}{N}
$$

\section{Keterangan:}

$\mathrm{H}^{\prime} \quad$ = indeks keanekaragaman ShannonWiener

$P i \quad=$ proporsi jenis ke- $\mathrm{i}$

$n i \quad=$ jumlah individu jenis ke-i

$N \quad=$ jumlah individu total seluruh jenis

Jenis paku epifit yang dominan dapat diketahui dengan menghitung Indeks Nilai Penting (INP) yang merupakan penjumlahan dari Kerapatan Relatif (KR) dan Frekuensi Relatif (FR) (Odum 1993). Indeks nilai penting dapat memberikan gambaran mengenai karakter sosiologi suatu jenis tumbuhan dalam komunitas (Prastyo et al. 2015).

Kerapatan Mutlak (KM):

$$
(\mathrm{KM})=\frac{\text { Jumlah individu suatu jenis }}{\text { Luas total plot pengamatan }}
$$


Kerapatan Relatif (KR):

$$
(\mathrm{KR})=\frac{\text { Kerapatan mutlak suatu jenis }}{\text { Jumlah kerapatan semua jenis }} \times 100 \%
$$

Frekuensi Mutlak (FM):

$$
(\mathrm{FM})=\frac{\text { Jumlah plot ditemukannya suatu jenis }}{\text { Jumlah seluruh plot pengamatan }}
$$

Frekuensi Relatif (FR):

$$
(\mathrm{FR})=\frac{\text { Frekuensi mutlak suatu jenis }}{\text { Jumlah frekuensi semua jenis }} \times 100 \%
$$

Indeks Nilai Penting (INP):

$$
\mathrm{INP}=\mathrm{KR}+\mathrm{FR}
$$

Kaitan antara jenis paku epifit terhadap kondisi iklim mikro dan tekstur permukaan pohon inang Gymnospermae dianalisis menggunakan Analisis Komponen Utama (AKU) program Minitab 16 statistical software.

\section{HASIL}

Kondisi Iklim Mikro di Kebun Raya Cibodas dan Data Iklim Berdasarkan BMKG Stasiun Meteorologi Citeko, Bogor. Pengamatan jenis paku epifit pada pohon inang Gymnospermae di Kebun Raya Cibodas dilakukan pada tiga lokasi yang cukup representatif terhadap keanekaragaman paku epifitnya (Gambar 1). Lokasi pertama berada di sekitar Pintu 3 Kebun Raya Cibodas (vak V.C), lokasi kedua merupakan taman terbuka di sekitar guest house (vak III.A), dan lokasi ketiga berada di sekitar Gedung Pengelola Kebun Raya Cibodas (vak XIII.A). Pengukuran kondisi iklim mikro dilakukan pada dua posisi ketinggian yang berbeda, yaitu pada ketinggian 0-1 meter dan ketinggian 1-2 meter. Kondisi iklim mikro yang diamati meliputi suhu udara $\left({ }^{\circ} \mathrm{C}\right)$, kelembapan udara $(\%)$, intensitas cahaya (Lux), dan kecepatan angin (m/s) (Tabel 1).

Lokasi pertama vak V.C memiliki rentang suhu udara paling tinggi di ketinggian 0-1 meter sebesar $22.80-27.50^{\circ} \mathrm{C}$, sedangkan pada lokasi kedua vak III.A memiliki rentang suhu sebesar $22.40-25.20^{\circ} \mathrm{C}$, dan lokasi ketiga vak XIII.A memiliki rentang suhu sebesar $21.40-27.20^{\circ} \mathrm{C}$. Rentang suhu udara dan kelembapan udara pada ketinggian 0-1 meter dan 1-2 meter relatif sama. Intensitas cahaya bervariasi di setiap lokasi pada setiap ketinggian yang berbeda, lokasi vak III.A memiliki intensitas cahaya cukup tinggi pada ketinggian pohon 1-2 meter yaitu 27743205 Lux. Kecepatan angin juga bervariasi di setiap lokasi dan setiap ketinggian yang berbeda, kecepatan angin masih di bawah $1 \mathrm{~m} / \mathrm{s}$ karena pepohonan cukup rapat menyebabkan angin tertahan.

Berdasarkan data iklim dari BMKG Stasiun Meteorologi Citeko, Bogor (Tabel 2), rerata suhu dan kecepatan angin dari bulan Januari 2017 sampai April 2019 memiliki variasi yang sangat kecil. Selisih kelembapan relatif memiliki nilai 4.15. Data BMKG tidak mencantumkan pengukuran intensitas cahaya.

Paku Epifit yang Menempati Pohon Inang Gymnospermae di Kebun Raya Cibodas. Paku epifit pada inang Gymnospermae di kawasan Kebun Raya Cibodas berjumlah 18 jenis, terdiri atas suku Aspleniaceae (Asplenium nidus), Athyriaceae (Deparia petersenii), Davalliaceae (Davallia denticulata, Davallia pentaphylla, Davallia repens, Davallia trichomonaides), Oleandraceae (Oleandra pistillaris), Polypodiaceae (Adiantum raddianum, Belvisia spicata, Goniophlebium percisifolium, Goniophlebium subauriculatum, Microsorum insigne, Pyrrosia albicans, Selliguea enervis), Selaginellaceae (Selaginella opaca, Selaginella uncinata), dan Vittariaceae (Antrophyum reticulatum, Vittaria elongata). Paku epifit yang memiliki indeks nilai penting tinggi adalah $D$. denticulata $(59.45 \%), \mathrm{V}$.

\begin{tabular}{|c|c|c|c|c|c|c|c|c|}
\hline \multirow{3}{*}{ Lokasi } & \multicolumn{8}{|c|}{ Posisi ketinggian pohon inang Gymnospermae } \\
\hline & \multicolumn{4}{|c|}{$\mathrm{A}$} & \multicolumn{4}{|c|}{ B } \\
\hline & $\begin{array}{l}\text { Suhu } \\
\left({ }^{\circ} \mathrm{C}\right)\end{array}$ & $\begin{array}{l}\text { KR } \\
(\%)\end{array}$ & $\begin{array}{l}\text { IC } \\
\text { (Lux) }\end{array}$ & $\begin{array}{l}\text { KA } \\
(\mathrm{m} / \mathrm{s})\end{array}$ & $\begin{array}{l}\text { Suhu } \\
\left({ }^{\circ} \mathrm{C}\right)\end{array}$ & $\begin{array}{l}\text { KR } \\
(\%)\end{array}$ & $\begin{array}{l}\text { IC } \\
\text { (Lux) }\end{array}$ & $\begin{array}{l}\text { KA } \\
(\mathrm{m} / \mathrm{s})\end{array}$ \\
\hline$\overline{\text { Vak }}$ & $22,80-$ & $72,56-$ & $1883-$ & $0,41-$ & $23,00-$ & $72,10-$ & $2514-$ & $0,14-$ \\
\hline V.C & 27,50 & 73,20 & 2046 & 0,82 & 27,50 & 72,89 & 3123 & 0,73 \\
\hline Vak & $22,40-$ & $75,72-$ & $2855-$ & $0,46-$ & $22,40-$ & $75,45-$ & 2774- & $0,16-$ \\
\hline III.A & 25,20 & 76,25 & 3132 & 0,63 & 25,20 & 76,21 & 3205 & 0,77 \\
\hline Vak & $21,40-$ & $74,93-$ & $2342-$ & $0,00-$ & $21,20-$ & $74,85-$ & 2129- & $0,04-$ \\
\hline XIII.A & 27,20 & 76,30 & 2433 & 0,11 & 27,30 & 75,86 & 2398 & 0,29 \\
\hline
\end{tabular}
elongata (44.72\%), dan G. subauriculatum $(31.87 \%)$ (Tabel 3).

Tabel 1. Kondisi iklim mikro bulan Januari sampai April 2019 pada tiga lokasi pengamatan jenis paku epifit di Kebun Raya Cibodas

A: posisi ketinggian pohon inang 0-1 meter, B: posisi ketinggian pohon inang 1-2 meter, RH: kelembapan relatif, IC: intensitas cahaya, KA: kecepatan angin 
Tabel 2. Kondisi iklim berdasarkan data BMKG Stasiun Meteorologi Citeko, Bogor

\begin{tabular}{lccc}
\hline $\begin{array}{l}\text { Waktu } \\
\text { pengukuran }\end{array}$ & $\begin{array}{l}\text { Rerata } \\
\text { suhu }\left({ }^{\circ} \mathrm{C}\right)\end{array}$ & $\begin{array}{l}\text { Rerata } \\
\text { kelembapan } \\
\text { relatif }(\%)\end{array}$ & $\begin{array}{l}\text { Rerata } \\
\text { kecepatan } \\
\text { angin }(\mathrm{m} / \mathrm{s})\end{array}$ \\
\hline Jan-Des 2017 & 21.46 & 85.92 & 0.42 \\
Jan-Des 2018 & 21.44 & 84.08 & 0.37 \\
Jan-Apr 2019 & 21.48 & 88.23 & 0.41 \\
\hline
\end{tabular}

Tabel 3. Indeks nilai penting jenis paku epifit pada tiga lokasi pengamatan di Kebun Raya Cibodas

\begin{tabular}{lccc}
\hline Nama jenis & $\begin{array}{c}\text { Kerapatan } \\
\text { relatif }(\%)\end{array}$ & $\begin{array}{c}\text { Frekuensi } \\
\text { relatif }(\%)\end{array}$ & $\begin{array}{c}\text { Indeks nilai } \\
\text { penting (\%) }\end{array}$ \\
\hline A. nidus & 0.10 & 1.12 & 1.22 \\
A. raddianum & 0.29 & 1.12 & 1.41 \\
A. reticulatum & 6.58 & 2.25 & 8.82 \\
B. spicata & 0.58 & 1.12 & 1.70 \\
D. denticulata & 38.10 & 21.35 & $59.45^{*}$ \\
D. pentaphylla & 0.77 & 1.12 & 1.90 \\
D. petersenii & 0.19 & 2.25 & 2.44 \\
D. repens & 10.83 & 7.87 & 18.70 \\
D. trichomonaides & 2.90 & 3.37 & 6.27 \\
G. percisifolium & 0.10 & 1.12 & 1.22 \\
G. subauriculatum & 12.77 & 19.10 & 31.87 \\
M. insigne & 0.97 & 5.62 & 6.59 \\
O. pistillaris & 0.10 & 1.12 & 1.22 \\
P. albicans & 0.58 & 1.12 & 1.70 \\
S. enervis & 1.55 & 5.62 & 7.17 \\
S. opaca & 0.19 & 1.12 & 1.32 \\
S. uncinata & 1.16 & 1.12 & 2.28 \\
V. elongata & 22.24 & 22.47 & 44.72 \\
\hline Total & 100 & 100 & 200 \\
\hline
\end{tabular}

*: Jenis paku dengan INP tertinggi

Pohon inang Gymnospermae yang ditempati oleh paku epifit berjumlah 15 jenis, terdiri atas suku Araucariaceae (Agathis borneensis, Araucaria angustifolia, Araucaria bidwillii, Araucaria columnaris, Araucaria cunninghamii), Cupressaceae (Cupressus goveniana, Juniperus procera, Taxodium huegelii), Pinaceae (Keteleeria davidiana, Pinus kesiya, Pinus merkusii, Pinus oocarpa, Pinus parviflora, Pinus patula), dan Podocarpaceae (Dacrycarpus imbricatus). Jumlah total pohon inang sebanyak 47 pohon. Pohon inang yang terbanyak ditemukan adalah $A$. cunninghamii sebanyak 7 pohon, P. parviflora 6 pohon, dan $P$. kesiya 5 pohon. Pohon inang $A$. bidwillii ditempati paku epifit dengan jumlah jenis paku epifit terbanyak yaitu 9 jenis, sedangkan pohon inang $K$. davidiana dan $A$. columnaris hanya ditempati oleh satu jenis paku epifit saja (Tabel 4). Jenis paku epifit $V$. elongata menempati hampir semua jenis pohon inang, sebanyak 14 jenis pohon inang ditempati oleh paku ini kecuali pohon inang A. columnaris. Davallia denticulata menempati 13 jenis pohon inang, dan G. subauriculatum menempati 11 jenis pohon inang (Tabel 4).

Hasil perhitungan nilai indeks keanekaragaman Shannon-Wiener (H') menunjukkan nilai H' pada masing-masing lokasi berada dalam rentang indeks $\mathrm{H}^{\prime}=1-3$ yang menandakan keanekaragaman sedang (Tabel 5). Nilai H' paling tinggi dimiliki oleh lokasi ketiga vak XIII.A sebesar 1.76. Perbedaan nilai H' pada lokasi pertama vak V.C dan lokasi kedua vak III.A tidak begitu berbeda. Lokasi kedua memiliki indeks keanekaragaman paling rendah yaitu sebesar 1.44 .

Faktor yang Mempengaruhi Keanekaragaman Jenis Paku Epifit. Sebaran jenis paku epifit pada pohon inang Gymnospermae dipengaruhi oleh kekasaran tekstur permukaan pohon inang yang terdapat pada komponen pertama serta ketebalan kulit pohon yang terdapat pada komponen kedua (Gambar 2). Variabel yang memiliki nilai -1 sampai 1 berpengaruh kuat terhadap komponen, sedangkan variabel yang memiliki nilai mendekati 0 berpengaruh lemah terhadap komponen. Kekasaran permukaan kulit pohon inang Gymnospermae memiliki nilai variabel mendekati satu pada komponen pertama. Ketebalan permukaan kulit pohon inang juga memiliki nilai variabel mendekati satu pada komponen kedua. Ketinggian, kelembapan relatif, dan kecepatan angin memiliki nilai variabel mendekati satu pada komponen kedua, sehingga memiliki pengaruh kuat terhadap komponen kedua. Suhu udara memiliki nilai mendekati satu, artinya suhu udara berpengaruh kuat terhadap komponen pertama (Gambar 3).

Ketebalan dan kekasaran permukaan pohon inang Gymnospermae bervariasi. Ketebalan permukaan pohon inang Gymnospermae mulai dari 0.08-2.76 cm. Kekasaran permukaan pohon inang Gymnospermae digolongkan menjadi beberapa kategori dari sangat halus sampai sangat kasar. Permukaan pohon inang A. cunninghamii dikategorikan sangat halus dengan ketebalan permukaan pohon inang $0.08-0.53 \mathrm{~cm}$. Permukaan pohon inang $P$. kesiya, $P$. merkusii, dan $P$. oocarpa dikategorikan sangat kasar. Ketebalan permukaan pohon P. kesiya dapat mencapai $2.76 \mathrm{~cm}$ (Ganbar 4). 


\section{PEMBAHASAN}

Paku epifit pada pohon inang Gymnospermae di kawasan Kebun Raya Cibodas berjumlah 18 jenis termasuk dalam 7 suku. Jenis paku epifit paling banyak menempati pohon inang $A$. bidwillii, yaitu
Tabel 5. Indeks keanekaragaman Shannon-Wiener (H') pada lokasi pengamatan di Kebun Raya Cibodas

\begin{tabular}{lc}
\hline Lokasi & $\mathrm{H}^{\prime}$ \\
\hline Vak V.C & 1.46 \\
Vak III.A & 1.44 \\
Vak XIII.A & 1.76 \\
\hline
\end{tabular}

Tabel 4 Jenis paku epifit yang menempati pohon inang Gymnospermae di Kebun Raya Cibodas

\begin{tabular}{|c|c|c|c|c|c|c|c|c|c|c|c|c|c|c|c|c|}
\hline Paku epifit & & & & & & & & Pohon & inang & & & & & & & \\
\hline & A.bor & A.ang & A.bid & A.col & A.cun & C.gov & D.imb & J.pro & $K . d a v$ & P.kes & P.mer & P.ooc & P.par & P.pat & T.hug & Tiotal \\
\hline A. nidus & & & $\mathrm{x}$ & & & & & & & & & & & & & 1 \\
\hline A. raddianum & & & & & & $\mathrm{x}$ & & & & & & & & & & 1 \\
\hline A. reticulatum & & & & & $\mathrm{x}$ & $\mathrm{x}$ & & & & & & & & & & 2 \\
\hline B. spicata & & & & & $\mathrm{x}$ & & & & & & & & & & & 1 \\
\hline D. denticulata & & $\mathrm{x}$ & $\mathrm{x}$ & $\mathrm{x}$ & $\mathrm{x}$ & $\mathrm{x}$ & $\mathrm{x}$ & $\mathrm{x}$ & & $\mathrm{x}$ & $\mathrm{x}$ & $\mathrm{x}$ & $\mathrm{x}$ & $\mathrm{x}$ & $\mathrm{x}$ & 13 \\
\hline D. pentaphylla & & $\mathrm{x}$ & & & & & & & & & & & & & & 1 \\
\hline D. petersenii & & & $\mathrm{x}$ & & & & & & & & & & $\mathrm{x}$ & & & 2 \\
\hline D. repens & $\mathrm{x}$ & & & & $\mathrm{x}$ & & & & & $\mathrm{x}$ & $\mathrm{x}$ & & $\mathrm{x}$ & & $\mathrm{x}$ & 6 \\
\hline D. trichomonaides & & & & & & $\mathrm{x}$ & & & & & & $\mathrm{x}$ & $\mathrm{x}$ & $\mathrm{x}$ & & 4 \\
\hline G. percisifolium & & & & & & & & & & $\mathrm{x}$ & & & & & & 1 \\
\hline G. subauriculatum & $\mathrm{x}$ & $\mathrm{x}$ & $\mathrm{x}$ & & $\mathrm{x}$ & $\mathrm{x}$ & & $\mathrm{x}$ & & $\mathrm{x}$ & $\mathrm{x}$ & $\mathrm{x}$ & $\mathrm{x}$ & $\mathrm{x}$ & & 11 \\
\hline M. insigne & & & $\mathrm{x}$ & & $\mathrm{x}$ & $\mathrm{x}$ & $\mathrm{x}$ & & & & & & & & & 4 \\
\hline O. pistillaris & & & & & & & & & & & & $\mathrm{x}$ & & & & 1 \\
\hline P. albicans & & & $\mathrm{x}$ & & & & & & & & & & & & & 1 \\
\hline S. enervis & $\mathrm{x}$ & & $\mathrm{x}$ & & & & & & & & $\mathrm{x}$ & $\mathrm{x}$ & & & & 3 \\
\hline S. opaca & & & $\mathrm{x}$ & & & & & & & & & & & & & 1 \\
\hline S. uncinata & & & & & & & $\mathrm{x}$ & & & & & & & & & 1 \\
\hline V. elongata & $\mathrm{x}$ & $\mathrm{x}$ & $\mathrm{x}$ & & $\mathrm{x}$ & $\mathrm{x}$ & $\mathrm{x}$ & $\mathrm{x}$ & $\mathrm{x}$ & $\mathrm{x}$ & $\mathrm{x}$ & $\mathrm{x}$ & $\mathrm{x}$ & $\mathrm{x}$ & $\mathrm{x}$ & 14 \\
\hline
\end{tabular}

$\mathrm{x}$ : Jenis paku epifit yang menempati pohon inang

A.bor $=$ A. borneensis, A.ang $=$ A. angustifolia, A.bid $=$ A. bidwillii, A.col $=$ A. columnaris, A. cun $=$ A. cunninghamii, C. gov $=C$. goveniana, $D$. imb $=D$. imbricatus, $J$. pro $=J$. procera, $K$. dav $=K$. davidiana, P.kes $=P$. kesiya, $P$. mer $=P$. merkusii, P.ooc $=$ P. oocarpa, $P$. par $=$ P. parviflora, $P$. pat $=$ P. patula, $T$. hug $=$ T. huegelii

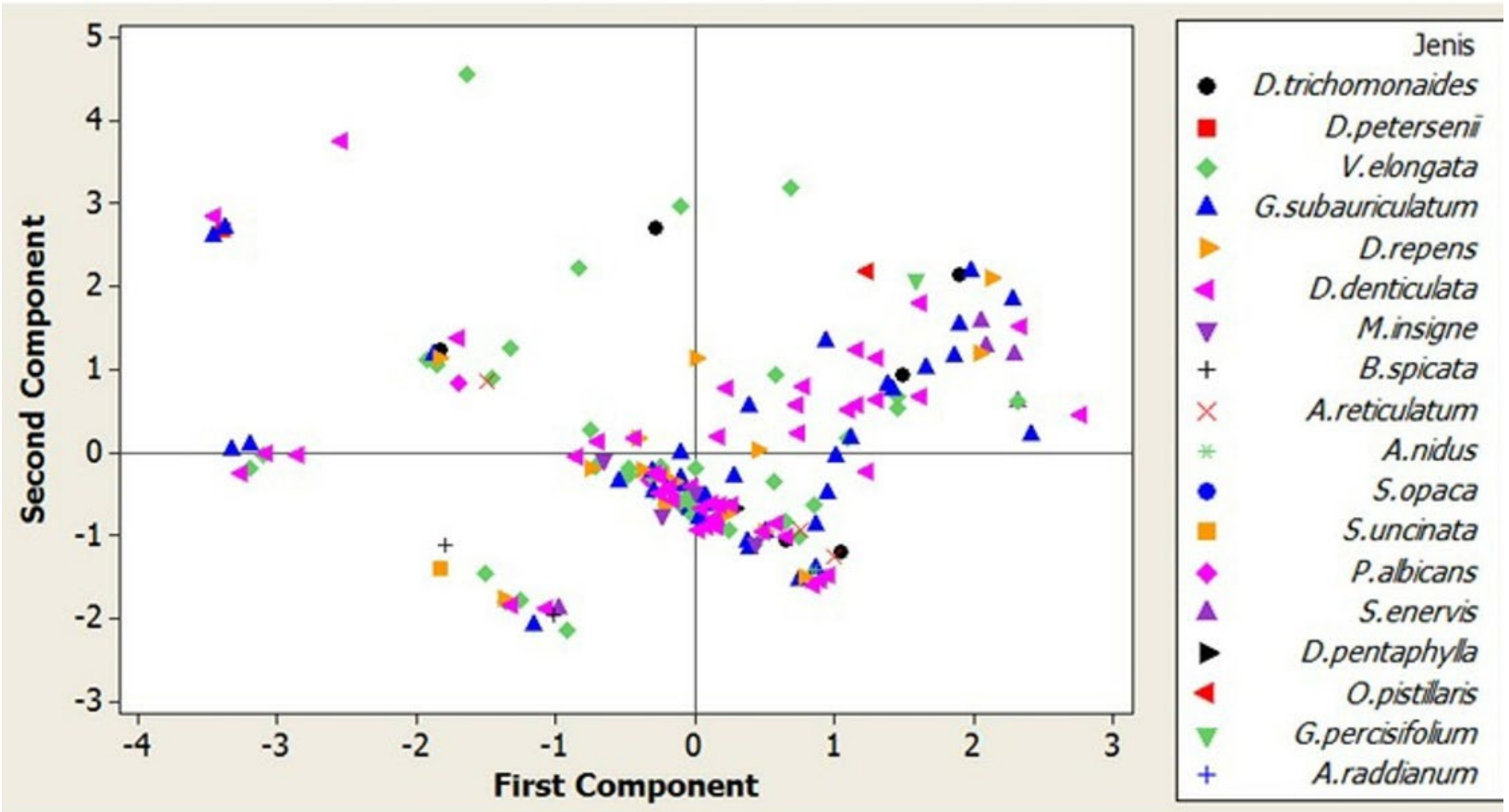

Gambar 2. Sebaran jenis paku epifit berdasarkan komponen pertama: kekasaran permukaan pohon dan komponen kedua: ketebalan kulit pohon inang 


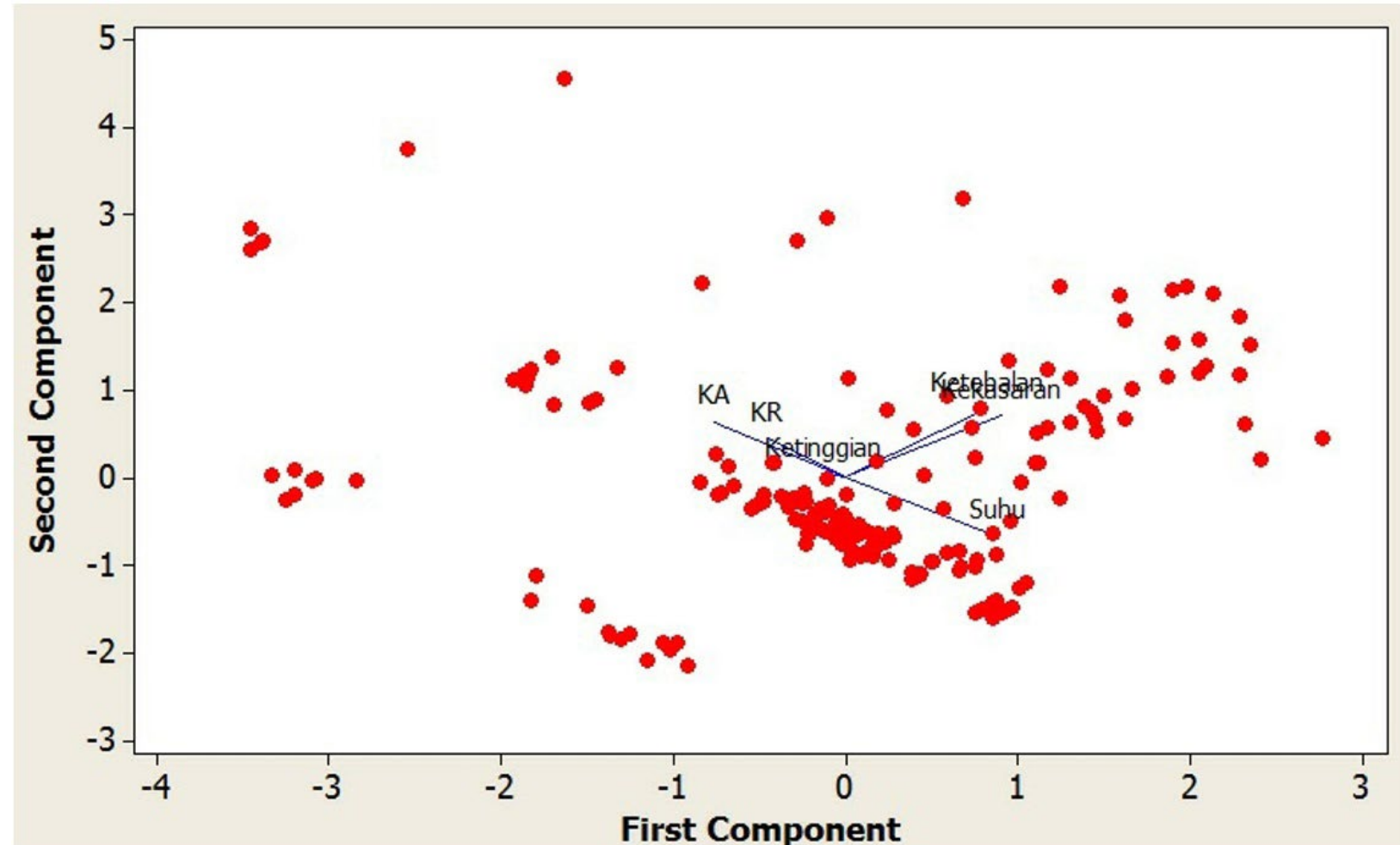

Gambar 3. Korelasi antara faktor lingkungan terhadap sebaran jenis paku epifit berdasarkan data iklim dari BMKG Stasium Meteorologi Citeko, Bogor

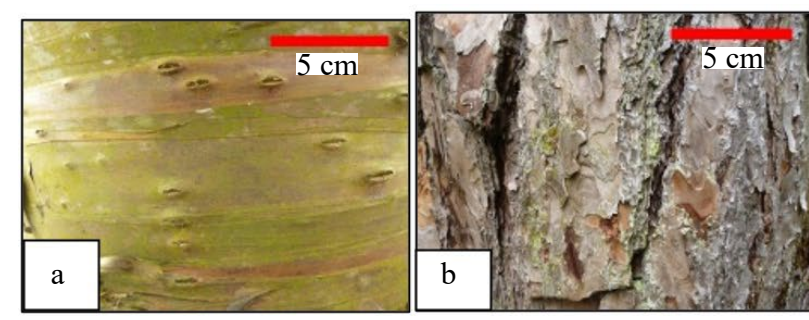

Gambar 4. Tekstur permukaan pohon inang (a) A. cunninghamii,
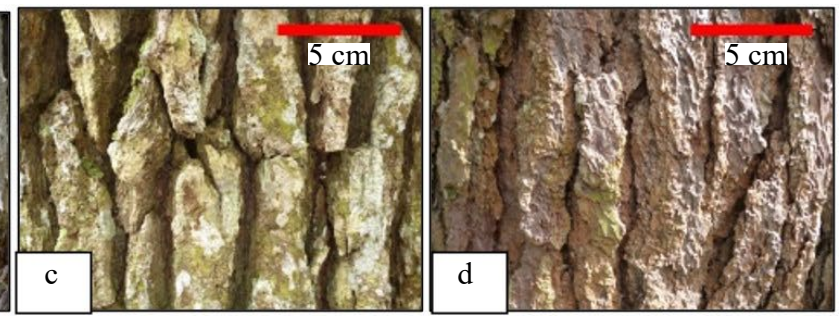

sebanyak 9 jenis paku epifit. Pohon A. bidwillii memiliki permukaan kulit pohon yang agak kasar, keras dan tebal. Menurut Nawawi et al. (2014) tumbuhan epifit cenderung menempel pada tumbuhan inang yang memiliki tekstur kulit tebal, beralur, berserabut dan keras. Tekstur permukaan pohon yang kasar cocok untuk menempelnya spora paku. Pohon A. cunninghamii dan C. goveniana juga ditempati banyak jenis paku epifit. Sebanyak 7 jenis paku epifit dapat ditemukan pada dua pohon tersebut. Pohon C. goveniana memiliki tekstur permukaan kulit pohon yang kasar dan tebal, sehingga spora paku mudah menempel pada permukaan pohon. Cupressus goveniana mempunyai tajuk yang rimbun dan melebar, sehingga cahaya matahari sulit masuk menembus tajuk menyebabkan keadaan di sekitar pohon tersebut lembap. Pohon A. columnaris dan $K$. davidiana memiliki tekstur permukaan pohon agak kasar namun hanya ditempati oleh 1 jenis paku epifit saja dan jumlahnya sedikit. Hal ini kemungkinan terjadi karena pohon inang $A$. columnaris dan $K$. davidiana tidak banyak memiliki celah pada permukaan kulit pohonnya. Selain tumbuh epifit pada Gymnospermae, beberapa paku seperti Asplenium nidus dan Davalia denticula juga dapat tumbuh pada Angiospermae yaitu kelapa sawit (Sofiyanti 2013). Kelapa sawit memiliki kulit batang kasar sehingga cocok ditumbuhi paku epifit. Kulit pohon yang kasar memiliki banyak celah yang dapat menyimpan air, sehingga kelembapan di kulit pohon lebih tinggi. Kelembapan dan tekstur kulit batang memegang peranan penting terhadap keberadaan paku epifit (Tewari et al. 2009).

Hasil perhitungan Indeks Nilai Penting (INP) menunjukkan jenis paku epifit yang memiliki nilai INP tinggi di kawasan Kebun Raya Cibodas ialah $D$. denticulata (59.45\%), V. elongata (44.72\%), dan G. subauriculatum (31.87\%). Menurut Aththorick et al. (2005), INP yang tinggi menggambarkan bahwa jenis tersebut dapat beradaptasi dengan baik terhadap lingkungannya. Tiga jenis paku epifit tersebut ditemukan di seluruh lokasi pengamatan. Davalia 
denticulata dapat hidup baik pada daerah teduh maupun terbuka. Hal inilah yang menyebabkan $D$. denticulata mudah ditemukan pada setiap lokasi pengamatan di Kebun Raya Cibodas. Vittaria elongata dan $G$. subauriculatum juga mudah ditemukan di seluruh lokasi pengamatan. Dua jenis tersebut cenderung ditemukan di bagian pangkal pohon inang. Menurut Setyawan (2000), tumbuhan epifit dari divisi Bryophyta dan Pteridophyta banyak ditemukan di bagian pangkal pohon karena kadar air pada pangkal batang relatif lebih tinggi daripada di ujung batang. Hal ini sesuai dengan kondisi iklim mikro di kawasan Kebun Raya Cibodas yang menunjukkan kelembapan pohon lebih tinggi di bagian pangkal pohon inang dibandingkan dengan kelembapan di bagian tengah pohon inang (Tabel 1).

Hasil perhitungan nilai indeks keanekaragaman Shannon-Wiener (H') menunjukkan nilai H' pada masing-masing lokasi dalam rentang indeks $\mathrm{H}^{\prime}=$ 1-3 yang menandakan keanekaragaman sedang. Nilai H' paling tinggi dimiliki oleh lokasi ketiga vak XIII.A sebesar 1.76. Perbedaan nilai H' pada lokasi pertama vak V.C dan lokasi kedua vak III.A tidak begitu berbeda. Lokasi kedua memiliki indeks keanekaragaman paling rendah yaitu sebesar 1,44. Kawasan Kebun Raya Cibodas berada pada ketinggian 1,300-1,425 m dpl. Lokasi kedua vak III.A memiliki ketinggian paling tinggi yaitu 1,381 m dpl, sedangkan pada lokasi pertama vak V.C memiliki ketinggian 1,317 $\mathrm{m}$ dpl dan pada lokasi ketiga vak XIII.A memiliki ketinggian 1,347 mdpl. Selisih ketinggian di atas tidak berbeda jauh; dengan selisih yang kecil diduga bahwa faktor ketinggian bukan menjadi hal utama yang membedakan pertumbuhan paku pada lokasi tersebut.

Keanekaragaman jenis paku-pakuan dipengaruhi oleh faktor lingkungan seperti sinar matahari, suhu, air, dan ketinggian tempat (Wahyuningsih et al. 2021). Semakin tinggi suatu tempat maka kelembapan udaranya meningkat dan suhu udara mengalami penurunan (Rudyarti 2012). Hal ini terjadi jika ketinggian tempatnya berbeda secara signifikan. Kondisi tersebut dapat menyebabkan tumbuhan sulit tumbuh, sehingga keanekaragaman jenisnya rendah. Menurut Holttum (1986), kondisi lingkungan di hutan tertutup ditandai dengan sedikitnya jumlah sinar yang menembus kanopi hingga mencapai permukaan tanah dan kelembapan udaranya sangat tinggi, dengan demikian paku hutan memiliki kondisi hidup yang seragam. Dalam penelitian ini, ketinggian tempat di tiga lokasi tidak berbeda jauh sehingga suhu dan kelembapan udaranya hampir mirip.
Berdasarkan hasil Analisis Komponen Utama diperoleh empat komponen utama (PC1-PC4) yang dipakai untuk menganalisis keragaman data karena nilai varians (eigenvalue) PC1-PC4 dapat mewakili $74.9 \%$ data. Angka ini termasuk cukup besar karena terbukti dapat menjelaskan lebih dari $50 \%$ varians dari variabel. Berdasarkan analisis tersebut, komponen yang sangat memengaruhi keanekaragaman jenis paku epifit adalah tekstur permukaan pohon inang meliputi kekasaran kulit pohon. Korelasi positif mendekati nilai satu ditunjukkan oleh faktor tersebut pada PC1. Faktor kedua adalah ketebalan kulit pohon. Permukaan pohon yang kasar dan tebal cenderung lebih banyak ditempati paku epifit. Kondisi permukaan kulit pohon inang yang lebih kasar dan tebal memungkinkan spora paku epifit menempel pada batang pohon.

Kelembapan pada ketinggian batang pohon 0-1 m sedikit lebih tinggi dibandingkan dengan ketinggian batang pohon 1-2 m (Tabel 1). Jenis paku epifit yang banyak dijumpai pada ketinggian batang pohon inang 0-1 meter adalah $D$. denticulata, $V$. elongata, G. subauriculatum, A. nidus, dan M. insigne. Jenis paku tersebut cenderung membutuhkan kondisi udara lebih lembap. Menurut Nawawi et al. (2014), jenis paku-pakuan yang hidup di pangkal batang pohon umumnya lebih toleran terhadap kondisi lingkungan yang teduh seperti $A$. nidus dan $D$. denticulata.

Kebun Raya Cibodas mengoleksi sekitar 100 jenis paku-pakuan yang terdapat di Koleksi Tematik Paku-pakuan (SINDATA-KRC 2019). Jenis paku-pakuan yang tumbuh liar di Kebun Raya Cibodas di antaranya adalah $A$. nidus, $A$. raddianum, $A$. reticulatum, $B$. spicata, $D$. denticulata, $D$. pentaphylla, $D$. petersenii, $D$. repens, D. trichomonaides, G. percisifolium, $G$. subauriculatum, $O$. pistillaris, $P$. albicans, $S$. enervis, $S$. opaca, $S$. uncinata, dan $V$. elongata (Nasution dan Junaedi 2017). Microsorum insigne dapat ditemukan di tiga lokasi pengamatan. Hal ini mungkin terjadi karena spora paku tersebut dapat diterbangkan angin sehingga penyebarannya lebih luas.

Sembilan dari 18 jenis paku yang menempati pohon inang Gymnospermae telah dikoleksi di Koleksi Tematik Paku-pakuan Kebun Raya Cibodas. Jenis paku yang terdapat di tempat tersebut adalah $A$. nidus, D. denticulata, $D$. pentaphylla, D. petersenii, D. repens, G. subauriculatum, M. insigne, S. opaca, dan V. elongata (SINDATA-KRC 2019). Koleksi paku di Kebun Raya Cibodas didominasi oleh paku terestrial. Kebun Raya Cibodas belum memiliki 
tempat khusus untuk koleksi paku epifit. Koleksi paku epifit ditanam bersama dengan koleksi paku terestrial dengan melakukan modifikasi tempat tumbuh seperti ditanam pada batang paku tiang dan ditanam di atas permukaan tanah yang telah diberi cacahan pakis sebagai alas (Nasution 2015). Sembilan jenis paku epifit yang belum ada di Koleksi Tematik Paku-pakuan Kebun Raya Cibodas seperti jenis $A$. raddianum, $A$. reticulatum, $B$. spicata, $D$. trichomonaides, $G$. percisifolium, $O$. pistillaris, $P$. albicans, S. enervis, dan S. uncinata. Sebaiknya dikoleksi untuk memperkaya koleksi paku epifit di Koleksi Tematik Paku-pakuan Kebun Raya Cibodas juga dalam upaya konservasi paku epifit.

Paku epifit yang dijumpai pada Gymnospermae di Kebun Raya Cibodas berjumlah 18 jenis. Pohon inang Gymnospermae yang ditempati oleh paku epifit berjumlah 15 jenis termasuk dalam 4 suku. Tiga jenis paku epifit yang mempunyai INP tinggi adalah $D$. denticulata $(59.45 \%)$, $V$. elongata (44.72\%), dan G. subauriculatum (31.87\%). Faktor utama yang memengaruhi keanekaragaman jenis paku epifit adalah kekasaran dan ketebalan permukaan kulit pohon inang.

\section{DAFTAR PUSTAKA}

Aththorick TA, Nursahara P, Yulinda. 2005. Komposisi dan stratifikasi makroepifit di Hutan Wisata Tangkahan Taman Nasional Gunung Leuser Kabupaten Langkat. Jurnal Komunikasi Penelitian 17:1-8.

Holttum RE. 1986. Studies in the fern-genera allied to Tectaria $V$ Triplophyllum, a new genus of Africa and America. Kew Bull 41:237-260. https://doi.org/10.2307/4102928

Hutasuhut MA, Febriani H. 2019. Keanekaragaman paku-pakuan terestrialdi kawasan Taman Wisata Alam Sicike-Cike. Jurnal Biolokus 21:46-157.

[KRC-LIPI] Kebun Raya Cibodas-Lembaga Ilmu Pengetahuan Indonesia. 2019. Sejarah Kebun Raya Cibodas. Tersedia di: https://krcibodas.lipi.go.id/ [Tanggal diakses: 5 Mei 2019]

Lestaria I, Murningsiha, Utamia S. 2019. Keanekaragaman jenis tumbuhan paku epifit di Hutan Petungkriyono Kabupaten Pekalongan, Jawa Tengah. NICHE Journal of Tropical Biology 2:14-21.

Nasution T. 2015. Upaya konservasi ex situ dan in situ pakupakuan pegunungan di Kebun Raya Cibodas, Jawa Barat. Pros Sem Nas Masy Biodiv Indo 1:1392-1396. https:// doi.org/10.13057/psnmbi/m010622

Nasution T, Junaedi DI. 2017. Keanekaragaman dan komposisi tumbuhan epifit berpembuluh pada paku tiang (Cyathea spp.) di Kebun Raya Cibodas, Jawa Barat. Pros Sem Nas Masy Biodiv Indo 3:453-460.
Nainggolan AF. 2014. Keanekaragaman jenis paku epifit dan pohon inangnya di kawasan kampus IPB Dramaga Bogor, Jawa Barat [Skripsi]. Bogor: Institut Pertanian Bogor.

Nawawi GRN, Indriyanto, Duryat. 2014. Identifikasi jenis epifit dan tumbuhan yang menjadi penopangnya di blok perlindungan dalam kawasan Taman Hutan Raya Wan Abdul Rachman. J Sylva Lestari 2:39-48.

Odum EP. 1993. Dasar-Dasar Ekologi. Yogyakarta: Gadjah Mada University Pr.

Othman R, Latiff NHM, Tukiman I, Hasyim KSHY. 2015. Effects of altitude and microclimate on the distribution ferns in and urban areas. J Teknol 77:125-131. https://doi. org/10.11113/jt.v77.6876

Palinkas LA, Horwitz SM, Green CA, Wisdom JP, Duan N, Hoagwood K. 2015. Purposeful sampling for qualitative data collection and analysis in mixed method implementation research. Adm Policy Ment Health 42:533-544. https:// doi.org/10.1007/s10488-013-0528-y

Prastyo WR, Heddy S, Nugroho A. 2015. Identifikasi tumbuhan paku epifit pada batang tanaman kelapa sawit (Elaeis guineensis J.) di lingkungan Universitas Brawijaya. Jurnal Produksi Tanaman 3:65-74.

Rudyarti E. 2012. Persebaran dan keanekaragaman jenis tumbuhan paku-pakuan pada ketinggian yang berbeda di daerah terbuka dan tertutup kawasan Hutan Bebeng, Cangkringan, Sleman, Yogyakarta [Thesis]. Yogyakarta: Universitas Negeri Yogyakarta.

Setyawan AD. 2000. Tumbuhan epifit pada tegakan pohon Schima wallichii (D.C.) Korth. di Gunung Lawu. Biodiversitas 1:14-20. https://doi.org/10.13057/biodiv/d010102

[SINDATA-KRC] Sistem Informasi Data Tanaman-Kebun Raya Cibodas. 2019. Koleksi Paku-pakuan. Tersedia di: https:// sindata.krcibodas.lipi. go.id/ [Tanggal diakses: 15 Juli 2019]

Sofiyanti N. 2013. Keanekargaman jenis paku epifit yang tumbuh pada batang kelapa sawit (Elaeis guineensis Jacq.) di Pekanbaru, Riau. Jurnal Biologi 17:51-55.

Spellerberg IF, Fedor PJ. 2003. A tribute to Claude Shannon (1916-2001) and a plea for more rigorous use of species richness, species diversity and the 'Shannon-Wiener' Index. Glob Ecol Biogeogr 12:177-179. https://doi. org/10.1046/j.1466-822X.2003.00015.x

Sujalu AP. 2007. Identifikasi keanekaragaman paku-pakuan (Pteridophyta) epifit pada hutan bekas tebangan di Hutan Penelitian Malinau Cifor Seturan. Media Konservasi 12:38-48.

Tewari LM, Tewari G, Nailwal T, Pangtey YPS. 2009. Bark factors affecting the distribution of epiphytic ferns communities. Nat Sci 7:76-81.

Ulum FB, Setyati D. 2015. Tumbuhan paku (Pteridophyta) epifit di Gunung Raung, Banyuwangi, Jawa Timur, Indonesia. JID 16:7-12. https://doi.org/10.19184/jid.v16i1.1486

Wahyuningsih S, Achyani, Santoso H. 2021. Faktor biotik dan abiotic yang mendukung keragaman tumbuhan paku (Pteridophyta) di KAwasan Hutan Gisting Permai Kabupaten Tanggamus Lampung. Biolova 2:64-71. https:// doi.org/10.24127/biolova.v2i1.293

Wyse SV, Burns BR. 2011. Do host bark traits influence trunk epiphyte communities? NZ J Ecol 35:296-301. 